\title{
ВЛИЯНИЕ БИОПРЕПАРАТОВ НА УРОЖАЙНОСТЬ ЗДОРОВЫХ И ПОРАЖЕННЫХ ФОМОЗОМ КЛУБНЕЙ КАРТОФЕЛЯ
}

\author{
Андрийчук Т., Скорейко А. \\ Украинская научно-исследовательская станция карантина растений \\ Института защиты растений НААН,г. Черновщьы, Украина, email:ukrndskr@gmail.com \\ https://doi.org/10.53040/9789975347204.09
}

\begin{abstract}
The results of studies on the effect of Trichodermin, Gaupsin, PhytoDoctor, Planriz on the yield of healthy and phomosis-affected potato tubers are presented. The positive effect of all applied biological products on potato productivity is shown. Pre-planting treatment and two foliar spraying contributed to an increase in yields, both infected (by 2.3-11.7\%) with phomosis, and healthy (by $7.9-16.4 \%$ ) potato tubers.
\end{abstract}

\section{Введение}

Фомоз картофеля - опасное заболевание, приводящее к ухудшению семенных качеств посадочного материала, снижению урожайности и вызывающее значительные потери картофеля при хранении.

Болезнь может вызываться двумя вариативными формами Phoma exigua: $P$. exigua Desm. var. exigua или $P$. exigua Desm.var. foveata (Foister) Boerema. Первая является широко распространенным грибом в почве, имеет широкий круг растенийхозяев и является менее патогенной, чем $P$. exigua var. foveata. Последняя поражает главным образом картофель и при благоприятных условиях может привести к значительным экономическим потерям, нередко превышающим 25 \% [1, 2,3].

Значительные успехи в развитии химии обусловили то обстоятельство, что химический метод защиты растений стал ведущим. Интенсивное и широкое применение химических средств очень скоро выявило все свои отрицательные стороны с санитарно-гигиеническими и экологическими тревогами: загрязнение окружающей среды, снижение эффекта в результате возникновения новых, более устойчивых популяций возбудителей, токсичность для организмов не-мишеней, гибель диких животных, птиц, рыб, нарушения в ряде звеньев биоценоза, сопровождающееся накоплением токсичных веществ в растениях, кормах, пище. Это обусловливает поиск новых перспективных направлений в сельском хозяйстве с использованием технологий, безопасных для здоровья человека, животных и биоты в целом.

Среди методов интегрированной системы защиты растений важное место принадлежит биологической защите растений. 
Для защиты растений от возбудителей болезней созданы препараты на основе бактерий и грибов, налажен их выпуск. Так, на основе Bacillus subtilis разработаны препараты Фитоспорин, Фитоцид [4], которые эффективны против фитопатогенных микроорганизмов. Эффективным является использование против почвенных фитопатогенов препарата Триходермин, который изготавливают на основе представителей рода Trichoderma - широко распространенного сапротрофного почвенного гриба. Грибы рода Trichoderma производят метаболиты с широким спектром антимикробной активности, такие как глиотоксин и глиовирин, а также конкурируют с фитопатогенами за питательные вещества. Trichoderma паразитирует на склероциях гриба Sclerotinia sclerotiorum, Rhizoctonia solani; активен в отношении грибов рода Alternaria, Ascochyta, Botrytis, Colletotrichum, Fusarium, Helminthosporium, Pythium, Phoma, Phytophthora, Verticillium [5-8].

Одной из составляющих экологического ведения сельского хозяйства является применение биологических препаратов, направленных на стимуляцию роста и развития растений, улучшение азотного и фосфорного питания растений. Перспективными в этом отношении являются бактерии рода Pseudomonas, продуцирующие сидерофоры, основное свойство которых - комплексирование доступного микроорганизмам железа, в отсутствие которого фитопатогенные грибы и другие микроорганизмы прекращают свое развитие. Характеризуются бактерии рода Pseudomonas еще и другими полезными свойствами. Они способны растворять фосфорные соединения, синтезировать регуляторы роста растений, а также утилизировать ксенобиотики. Антибиотик, продуцируемый бактериями рода Pseudomonas и идентифицированный как трополон, оказывет летальное действие в отношении ряда грибов, патогенных для растений (Helminthosporium cynodotis, Fusarium roseum, Colletotrichum graminicola, Diplodia zeae, Pyricularia oryzae). Он оказывает также летальное действие в отношении актиномицетов и дрожжевых грибов [9].

Целью наших исследований было изучение влияния биопрепаратов на урожайность здоровых и пораженных фомозом клубней картофеля.

\section{Материалы и методы}

Работу проводили на базе Украинской научно-исследовательской станции карантина растений Института защиты растений в течение 2014-2015 гг. Почвы на территории станции дерново-оподзоленные серые с содержанием гумуса $2,8 \%$; $\mathrm{pH}=$ 5,9; гидролитическая кислотность - 3,2 мг-экв .; 100 г почвы содержит $\mathrm{P}_{2} \mathrm{O}_{5}$ и $\mathrm{K}_{2} \mathrm{O}_{5}$ (в мг на 100 г почвы): 25,0 и 17,5 соответственно.

В опытах использовали восприимчивый к болезни сорт Забава.

Заражение клубней картофеля проводили путем внесения инокулюма (двухнедельная культура патогена $P$. exigua Desm. var. exigua) в лунки, сделанные пробковым сверлом в клубнях на глубину 10 мм. Инокулированные клубни хранились в течение 4-6 недель при 5-8 ${ }^{\circ} \mathrm{C}$ до проявления заболевания, после чего высаживались на опытном участке. Предпосадочную обработку клубней проводили путем их замачивания в растворах биопрепаратов.

Схема опыта:

1 - контроль - здоровые клубни без обработки;

2 - обработка здоровых клубней перед посадкой препаратом Гаупсин $(2$ л/т) +2 внекорневые обработки (5 л/га) тем же препаратом;

3 - обработка здоровых клубней перед посадкой препаратом Планриз (2 л/т) + 2 внекорневые обработки (0,5 л/га) тем же препаратом; 
4 - обработка здоровых клубней перед посадкой в почву препаратом Триходермин (2 л/т) + 2 внекорневые обработки (5 л/га) тем же препаратом;

5 - обработка здоровых клубней перед посадкой препаратом ФитоДоктор $(0,5$ кг/т) + 2 внекорневые обработки (0,7 кг/га) тем же препаратом;

6 - контроль - зараженные (искусственно) фомозом (Phoma exigua var. exigua) клубни;

7 - обработка зараженных клубней перед посадкой препаратом Гаупсин $(2$ л/т) + 2 внекорневые обработки (5 л/га) тем же препаратом;

8 - обработка зараженных клубней перед посадкой препаратом Планриз (2 л/т) + 2 внекорневые обработки (0,5 л/га) тем же препаратом;

9 - обработка зараженных клубней перед посадкой препаратом Триходермин (2 л/т) + 2 внекорневые обработки (5 л/га) тем же препаратом;

10 - обработка зараженных клубней перед посадкой препаратом ФитоДоктор $(0,6$ кг/т) + 2-3 внекорневые обработки (0,7 кг/га) тем же препаратом.

Повторность опыта 4-х кратная, по 20 клубней в каждой, площадь учетных участков - по 3,5 м² каждая.

Гаупсин - препарат комплексного действия на основе бактерий Pseudomonas aureofaciens (штаммы В-306 и В-111) с титром 5х109 спор в 1 мл. Препарат применяют на картофеле против фузариоза, фомоза, альтернариоза, ризоктониоза. Норма использования против комплекса болезней - 5 л/га; для предпосевной обработки семян - 2 л/т.

Планриз - микробиологический препарат фунгицидного и бактерицидного действия на основе ризосферных бактерий Pseudomonas fluorescens AР33 с титром $5 \times 10^{9}$ спор в 1 мл препарата. Биопрепарат применяют против фузариоза, мучнистой росы, фитофтороза, парши, черной ножки на овощных культурах и картофеле. Предпосевную обработку клубней картофеля проводят заблаговременно или в день посадки. Норма расхода - 2 л/т. Концентрация рабочего раствора для опрыскивания вегетирующих растений - 0,1-0,2 \%. Опрыскивание начинают с фазы 3-4 настоящих листьев.

Триходермин - препарат на основе гриба Trichoderma lignorum. Используется для защиты сельскохозяйственных культур против всех видов гнилей и болезней листового аппарата. Подавляет развитие фитопатогенов путем прямого паразитирования, конкуренцией за субстрат, выделением ферментов (хитиназы, целлюлоза, глюконазы). В процессе жизнедеятельности выделяет антибиотики: аламетицин, глиотоксин, вирилин, которые сдерживают развитие фитопатогенных грибов. Кроме этого, препарат усиливает процессы аммонификации и нитрификации, мобилизации фосфора и калия, обогащает почву подвижными формами питательных веществ.

Для обработки семян перед посевом используют 2 л/т; в период вегетации - 3-5 Л/Т.

ФитоДоктор (Спорофит) - препарат на основе бактерии Bacillus subtilis. Применяют на картофеле против ризоктониоза, фитофтороза, сухих гнилей. Семенной материал обрабатывают перед посадкой в норме 0,3-0,6 кг/т; вегетирующие растения - 0,5-0,7 кг/га; перед закладкой на хранение - 10-20 кг/га.

Определение влияния биопрепаратов на урожайность клубней картофеля проводили согласно общепринятой методике [10]. 


\section{Результаты и обсуждение}

Заложен полевой опыт по определению влияния биологических препаратов Гаупсин (5 л/т); Планриз (2 л/т); Триходермин (2 л/т); ФитоДоктор (20 л/т) на урожайность здоровых и искусственно зараженных фомозом растений картофеля. Исследованиями установлено положительное действие всех примененных биопрепаратов на урожайность картофеля. Использование биопрепаратов способствовало повышению урожайности, как зараженных (на 2,3-11,7 \%) фомозом, так и здоровых (на 7,9-16,4%) клубней картофеля (рис. 1, 2).

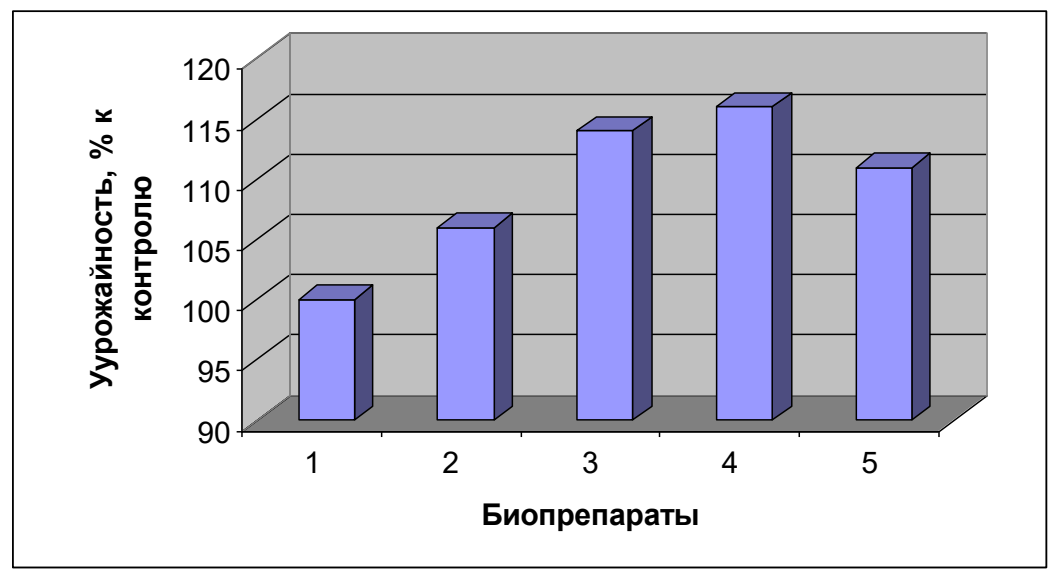

Рис. 1 - Влияние биопрепаратов на урожайность здоровых клубней картофеля: 1 - контроль - без обработки; 2 - Гаупсин; 3 - Планриз; 4 - Триходермин; 5 ФитоДоктор

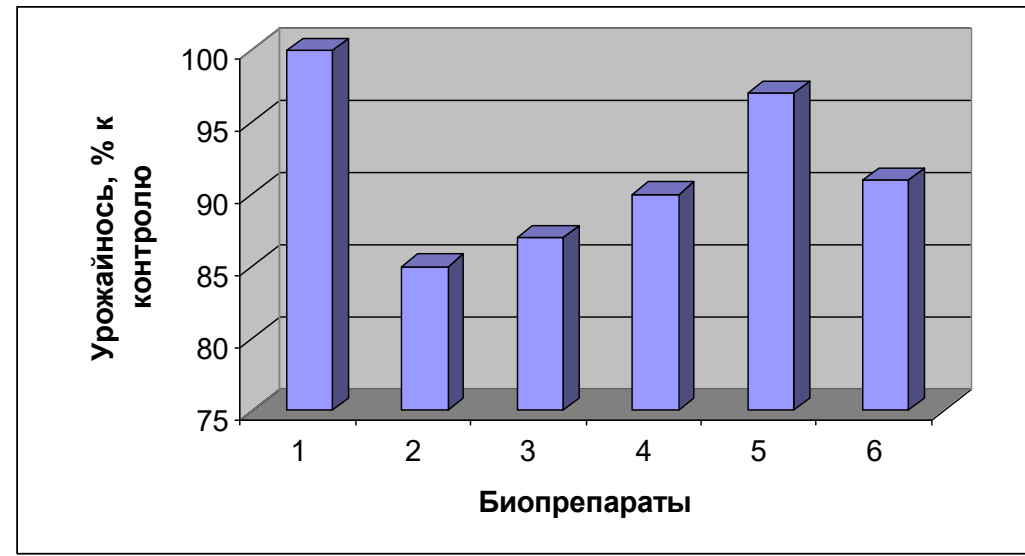

Рис. 2 - Влияние биопрепаратов на урожайность зараженных клубней картофеля: 1 здоровые, без обработки; 2 - зараженные, без обработки; 3 - Гаупсин; 4 - Планриз; 5 Триходермин; 6 - ФитоДоктор.

\section{Выводы}

Использование биопрепаратов способствовало повышению урожайности как зараженных (на 2,3-11,7 \%) фомозом, так и здоровых (на 7,9-16,4 \%) клубней картофеля. 


\section{Библиография}

1. Воловик А.С., Глез В.М. Защита картофеля от болезней, вредителей и сорняков. Справочник. Москва: Агропромиздат, 1987. С. 19-20.

2. Вредные организмы, имеющие карантинное значение для Европы. Информационные данные по карантинным вредным организмам для Европейского Союза и Европейской и Средиземноморской организации по защите растений (ЕОЗР) ; пер. с англ. Москва: Колос, 1996. 916 с.

3. Яковлева Н.П. Фитопатология. Программированное обучение. М.: Колос, 1983. C. 176-177.

4. Биофунгицид Фитоцид-р (10 мл) - защита от грибковых и бактериальных болезней. https://zelensvit.com/p283917062-biofungitsid-fitotsid-

zaschita.htmlMeтодические указания по государственным испытаниям фунгицидов, антибиотиков и протравителей семян сельскохозяйственных культур. Под ред. К.В. Новожилова. М.: ВИЗР, 1985. 130 с.

5. Николаева С.И., Штейнберг М. Е., Завелишко И. А., Харбур М. В., Андронаки Л. С. Антагонистическая и антибиотическая активность Trichoderma viride Pers. (Fr.) и Gliocladium virens Miller, Giddens et Foster. по отношению к Sclerotinium (Livb) D By. Микология и фитопатология. 1989. Т. 23, Вып. 2. С. 167-171.

6. Федоринчик Н.С. Trichoderma lignorum Hars. в биологической борьбе с возбудителями болезней растений. Микология и фитопатология. 1971. Т. 5. Вып 6. С. 499-505.

7. Штейнберг M.Е., Завелишко И. А., Ротаренко А. П., Андронаки Л. С. Gliocladium roseum Bainer и G.virens Miller (Giddens et Foster) и их микофильные свойства. Микология и фитопатология. 1991. Т. 25, Вып.1. С. 34-38.

8. Warum sind so schwer zu Fusarium und Verticillium bekampfen Luts Veronika. TASPO - Mag., 1986, № 1-2, P. 8 - 9 .

9. Lindberg G.D. An antibiotic lethal to fungi. Plant Disease, 1981. 65. 8. P. 680-683.

10. Методики випробування і застосування пестицидів ; за ред. проф. С.О. Трибеля. К.: Світ, 2001. 448 с. 